\title{
"The effects of perceived organizational support and social comparison on work attitudes"
}

\author{
Nuri Herachwati \\ AUTHORS \\ Jovi Sulistiawan (D) https://orcid.org/0000-0001-9910-3461 \\ Zainiyah Alfirdaus \\ Mario Gonzales B. N.
}

Nuri Herachwati, Jovi Sulistiawan, Zainiyah Alfirdaus and Mario Gonzales B. N.

ARTICLE INFO

(2018). The effects of perceived organizational support and social comparison on work attitudes. Problems and Perspectives in Management, 16(1), 12-21.

doi:10.21511/ppm.16(1).2018.02

DOI

http://dx.doi.org/10.21511/ppm.16(1).2018.02

RELEASED ON

Wednesday, 17 January 2018

RECEIVED ON

Thursday, 22 June 2017

ACCEPTED ON

Thursday, 12 October 2017

\section{(oc) EY-No}

LICENSE

This work is licensed under a Creative Commons Attribution-NonCommercial 4.0 International License

\section{JOURNAL}

"Problems and Perspectives in Management"

ISSN PRINT

$1727-7051$

ISSN ONLINE

$1810-5467$

PUBLISHER

LLC "Consulting Publishing Company "Business Perspectives"

FOUNDER

LLC "Consulting Publishing Company "Business Perspectives"

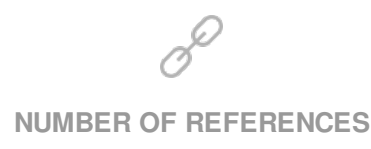

28

\section{NUMBER OF FIGURES}

1

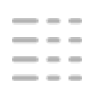

NUMBER OF TABLES

1

(C) The author(s) 2022. This publication is an open access article. 


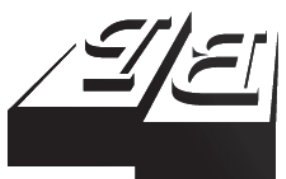

BUSINESS PERSPECTIVES

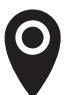

LLC "CPC "Business Perspectives" Hryhorii Skovoroda lane, 10, Sumy, 40022, Ukraine

www.businessperspectives.org

Received on: $22^{\text {nd }}$ of June, 2017 Accepted on: $12^{\text {th }}$ of October, 2017

(c) Nuri Herachwati, Jovi Sulistiawan, Zainiyah Alfirdaus, Mario Gonzales B. N., 2018

Nuri Herachwati, Lecturer, Department of Management, Faculty of Economics and Business, Universitas Airlangga, Indonesia.

Jovi Sulistiawan, Lecturer, Department of Management, Faculty of Economics and Business, Universitas Airlangga, Indonesia.

Zainiyah Alfrdaus, Student, Department of Management, Faculty of Economics and Business, Universitas Airlangga, Indonesia.

Mario Gonzales B. N., Student, Department of Management, Faculty of Economics and Business, Universitas Airlangga, Indonesia.

\section{(ㄷ)(1) $(8$}

This is an Open Access article, distributed under the terms of the Creative Commons Attribution-NonCommercial 4.0 International license, which permits re-use, distribution, and reproduction, provided the materials aren't used for commercial purposes and the original work is properly cited.
Nuri Herachwati (Indonesia), Jovi Sulistiawan (Indonesia),

Zainiyah Alfirdaus (Indonesia), Mario Gonzales B. N. (Indonesia)

\title{
ORGANIZATIONAL SUPPORT AND SOCIAL COMPARISON ON WORK ATTITUDES
}

\begin{abstract}
This study is based on the results of a survey research conducted by JobStreet Indonesia on its members, which has surprisingly found that more than $70 \%$ of employees lack clarity on the goals of their career. Drawing from the social exchange theory, employees tend to show positive work attitudes when they perceive that their organization paid attention to them. The objective of this study is to assess how significant the influence of Perceived Organizational Support (POS) is on career satisfaction, organizational commitment, and turnover intention. Besides organizational perspective, as stated by the social comparison theory, the way individuals perform both upward and downward comparisons could be expected to affect career satisfaction. Also, this research uses career commitment as a moderator variable that can strengthen or weaken the influence among variables, which is the employee's commitment towards their or ganization and competitiveness within their respective work group. The research has found some interesting results. It was shown that there is no significant relationship between POS and career satisfaction, career satisfaction and turnover intention, organizational support and turnover intention, and both upward and downward social comparison and turnover intention. The moderating effects of career commitment were not proven. In comparison, all of the moderating effects of a competitive work group were proven together with the relationship between upward social comparison and turnover intention.
\end{abstract}

\section{Keywords}

JEL Classification

social exchange theory, career satisfaction, organizational commitment, turnover intention

M54, J28, O15

\section{INTRODUCTION}

According to a survey by JobStreet Indonesia, $78.8 \%$ of respondents stated that they do not have a clear career opportunity in their current companies (www.portalhr.com). It has also been shown that career opportunity is the second-most important factor that influences employees in making the decision whether to move to another company or not (www.portalhr.com). The survey indicates that the majority of companies have not realized the importance of career to employees and how it might affect the organization.

The obscurity of career opportunity in a company causes employees to have the tendency to leave the company, which will be detrimental for the organization because career opportunity is one factor that is able to retain best talent (Barnett \& Bradley, 2007). Other than that, career satisfaction is also an important factor that is able to motivate and retain employees (Barnett \& Bradley, 2007; Kim et al., 2012; Lin \& Chen, 2004; Wang et al., 2012). In other words, company supporting career opportunities will cultivate the tendency for employees to stay in the company (Lin \& Chen, 2004). 
Lin and Chin (2004) stated that perceived organizational support (POS) is an important factor in predicting employee commitment towards the organization (organizational commitment). This goes in line with the social exchange theory which states that one should help those who had helped him (Gouldner, 1960). So, if an employee feels that the organization has supported his career, then the employee will feel obliged to stay in the company because the company has treated him well (Lin \& Chen, 2004).

It can be explained further that company support, either in the form of both social or material support, to an employee's personal goals will increase career satisfaction. On the other hand, if the employee feels that the organization does not support his personal goals, then this will hinder the achievement of the employee's personal goals and thus, it will reduce career satisfaction (Barnett \& Bradley, 2007; Chang, 1999).

In relation to the connection between career, commitment, and turnover intention, some researches have shown different results, depending on the employee's attitude towards his career. Employees with lower organizational commitment tend to leave the organization compared to those with higher organizational commitment. Also, it has been found that if an employee has a high career commitment, then that employee has a tendency to find opportunities that can fulfill his career needs (Lin \& Chen, 2004).

Career satisfaction is also influenced by how an employee compares his career achievements to those of his colleagues (Eddleston, 2009). This goes according to the social comparison theory (Eddleston, 2009), where one tends to compare himself with others who are more successful (upward) or those who are less successful (downward) than themselves. If a person tends to compare himself with another who is more successful or has a better performance, then his career satisfaction will tend to be lower. Conversely, if one compares himself with another who is less successful compared to himself, this activity will increase his self-esteem and pride on himself, thus increasing career satisfaction. A person with the tendency to perform upward comparison will increase the turnover intention of the organization (Eddleston, 2009). This is because the people with the tendency of performing upward comparison will find another job that can fulfill his need of self-improvement.

Other than from the organizational and individual aspects, team competition has also shown to reinforce the relationship between social comparison and career satisfaction and also turnover intention (Eddleston, 2009). This research intends to review the effect of career satisfaction to commitment towards the organization and also the intention to leave the organization as perceived from the perspective of the organization through organizational support and from the perspective of the individual through social comparison and the role of competitive work groups. Also, this research tries to discover the effect of moderation of career commitment and competition levels in work groups.

\section{LITERATURE REVIEW}

Perceived organizational support (POS) is a social exchange relationship which happens between the company and its employees. Eisenberger, Huntington, Hutchison and Sowa (1986) state that POS is an employee's general perception related to how far the organization cares about the employees, either on the value or the contribution given by the employee to the organization. A high perceived organizational support will trigger the emergence of a positive working attitude. The assumption that underlies the POS can be reviewed through the social exchange theory. In an organizational context, when an employee feel that the organization has given support to his career, then the employee will feel the need to stay in the company as a response to the positive treatment he has received from the company. In other words, the employee will become more bound to the organization when the employee feels that the organization has supported him (Lin \& Chen, 2004). Mowday, Steers, and Porter (1979) stated that the commitment towards the organization is a powerful relationship between the members of that organization with the organization itself, and 
the strong willingness of the employee to maintain membership within that organization and to achieve the goals of the organization. Based on these statements, then:

\section{H1: POS has a positive influence on organizan tional commitment.}

Tansky and Cohen (2001) in Lin and Chen (2004) proved that POS has a correlation with an employee's satisfaction and career development. This shows that thanks to organizational support to an employee's career development, the employee will feel more satisfaction towards his career. Subjective career success is often defined as similar to career satisfaction (Erdogan et al., 2004; Heslin, 2003; Ng et al., 2005; Seibert \& Kraimer, 2001). Subjective career success be interpreted as an employee's assessment about his career, such as a perception of career achievement and career future prospect (Aryee et al., 1994).

Barnett and Bradley (2007) stated that when an organization pays attention to the development of skills or the development of employee career, then the employee will be more satisfied towards his career. The employee will surely have expectations on the company, one of which is the expectation of receiving training or mentoring from the company. If the organization accommodates this hope, then the employee will feel that his skill or ability is improving and thus will improve his career satisfaction. Based on these statements, then:

\section{H2: POS has a positive influence on career satisfaction.}

Eddleston (2009) stated that human being tends to compare himself with others following the theory of social comparison (Eddleston, 2009). The theory of social comparison states that an individual tends to compare his abilities with the abilities of others. According to the theory of social comparison, there are two ways of how one person compares himself with others. The first one is an upward comparison: comparing himself with people who are better in terms of abilities, knowledge, career, and other aspects. A person with the tendency of performing upward comparison has a stronger motivation to be better than before. Second, the downward comparison: compar- ing himself with more inferior people. Eddleston (2009) states that one will compare himself with people not better than himself with the purpose of maintaining or reinforcing his own self-image. Downward comparison causes the individual to feel more comfortable with himself and with the current condition he is in.

Based on the perspective of the social comparison theory, a person will tend to feel dissatisfied with his career if there is a difference between what he wants and what he gets. Eddleston (2009) states that a person with the tendency to compare himself with people who are better than himself will feel dissatisfied with what he has achieved so far. On the contrary, when a person tends to compare himself with more inferior people, this will increase their self-esteem which will then create a sense of satisfaction with his career. Based on these statements, then:

H3: (a) Upward social comparison has a negas tive influence on career satisfaction, while (b) downward social comparison has a posip tive influence on career satisfaction.

When an employee feels satisfied with his career, then the employee will tend to commit to the organization. If the employee feels that the organization can fulfill the needs in terms of skill development, then the employee will feel satisfied towards his career and will feel more bound to the organization. Capelli (2000) states that the most important factor for employees who are joining or staying in a company is the potential room for career development and the opportunity to grow. This will then determine whether the employee is satisfied with his career or not. When the company is unable to give career satisfaction to the employee, then the employee will tend to try and find another company which is able to fulfill his career development needs. Also, when an employee receives support from the company towards his career development, then the employee will tend to stay in that company (Lin \& Chen, 2004). Based on this statement, then:

\section{H4: Career satisfaction has a positive influence on organizational commitment.}

According to Mobley (1977), turnover intention is defined as an evaluation of a person's current position in relation to that person's intention to leave 
the company and find another job. This turnover intention describes a person's intention to leave the company that he is currently working for and to find a job in another place. Abelson (1987) states that turnover intention consists of several components which occur in an individual. These components are the intention to quit, the intention to find other alternatives, the evaluation of those alternatives, and the intention to leave the organization. This is similar to what has been stated by Mobley (1977) that there are at least two intensity reinforcements to leave the organization which are the intensity to seek and the intensity to leave. It is further explained that the intensity to seek and the behavior to seek in general are understood as an aspect that precedes the intensity to leave and turnover. The main intensity deciding factor according to Mobley (1977) is satisfaction, expected attraction on an alternative job or opportunity. From these statements, we can infer that an individual can have the intention to leave the current organization because that individual felt dissatisfied with his current work condition. Therefore, that individual will try and find work opportunities which are more in line with his needs in other companies. Based on these statements, then:

\section{H5: Career satisfaction has a negative influence on turnover intention.}

An employee who has commitments towards the organization tends to have a lower intention to leave. The more an employee feels bound to the organization, as can be seen through his willingness to become more involved in the organizational goal achievement, the more said employee wants to stay as a part of the organization or, in other words, the lower the possibility for him to leave the organization (Lin \& Chen, 2004). Therefore, we can conclude that an employee with high organizational commitment will have lower intention to leave the organization. Conversely, if an employee has low organizational commitment, then that employee will be more likely to want to leave the organization.

H6: Organizational commitment has a negative influence on turnover intention.

An individual that performs upward comparison tends to focus on how other people perform better than himself. According to Eddleston (2009), this will cause a person to want to leave the organization because he has been comparing himself to people who perform better, which will increase a feeling of envy and inferiority, which will also increase the intention to leave the organization. On the other hand, downward comparison will make a person feel more comfortable with his current situation. Eddleston (2009) states that when a person has a tendency to perform downward comparison, then that person will tend to choose to stay with the organization. This is caused by the fact that downward comparison compares a person with more inferior people, thus making him feel better about his successes and this reduces his intention to leave the organization.

\section{H7: Upward social comparison has a positive ine fluence on turnover intention, while down- ward social comparison has a negative influ- ence on turnover intention.}

An employee's attitude towards his career will influence his attitude towards the current organization. So, an employee who is a part of an organization has his own career plans and his own expectations on how the organization will help him fulfill his goals. If the organization does as expected, which is supporting his career plans, then the employee will be committed to the organization (Chang, 1999). This commitment will grow stronger when the employee also has a high career commitment, which is his attitude towards his job and his involvement, or an employee's resolution towards his career (Wang et al., 2011). An employee with a high career commitment will have a high expectation towards his career. So, when an organization fulfills that expectation, the employee will tend to be more committed to the organization (Lin \& Chen, 2004).

\section{H8: The correlation between POS and orgae nizational commitment becomes stron- ger when the employee has a higher career commitment.}

Lin and Chen (2004) stated that the correlation between organizational commitment and turnover intention shows different results, depending on the employee's attitude towards his career. An employee with a higher career commitment will spend more time to improve his skills and will 
show little possibility to leave his career (Aryee \& Tan, 1992; Blau, 1989). However, if the organization does not fulfill his expectations on career development, the employee will prefer to leave the organization and find another organization which is more capable in fulfilling his career development needs. This indicates that this employee is not committed to the organization.

H9: The correlation between organizational commitment and turnover intention becomes stronger if the employee has a low career commitment.

The competition in work groups is usually focused on individual rankings in one group, including the success or failure level that has been experienced before. Competition has a different effect based on how a person performs his social comparison. Eddleston (2009) states that in a work group with higher competition, the existing members will feel more competitive towards the others. If the work group has a member with better performance, the other members with the tendency towards upward comparison will feel worse about themselves. This will reduce career satisfaction and increase the intention to leave the organization. Furthermore, Eddleston (2009) states that working in a work group with a high competition will tend to make employees with upward comparison to feel dis- satisfied with their career achievements and will also increase their intention to leave the organization. Conversely, working in the work group with a high level of rivalry between its members will make employees with the tendency of downward comparison to feel more satisfied with their career and decreases the intention to leave the organization (Eddleston, 2009).

H10: The level of rivalry in work groups will weaken the correlation between upward comparison and career success, and reinforce the correlation between downward comparison and career success.

H11: Competition levels in work groups will reinforce the correlation between upward comparison with the intention to leave the organization and will weaken the correlation between downward comparison and the intention to leave the organization.

\section{METHODOLOGY}

This research uses data obtained from questionnaires consisting of questions used to measure six different constructs required in this research. Respondents will answer the questions in the questionnaire using a Likert scale, from the value of 1 to represent a

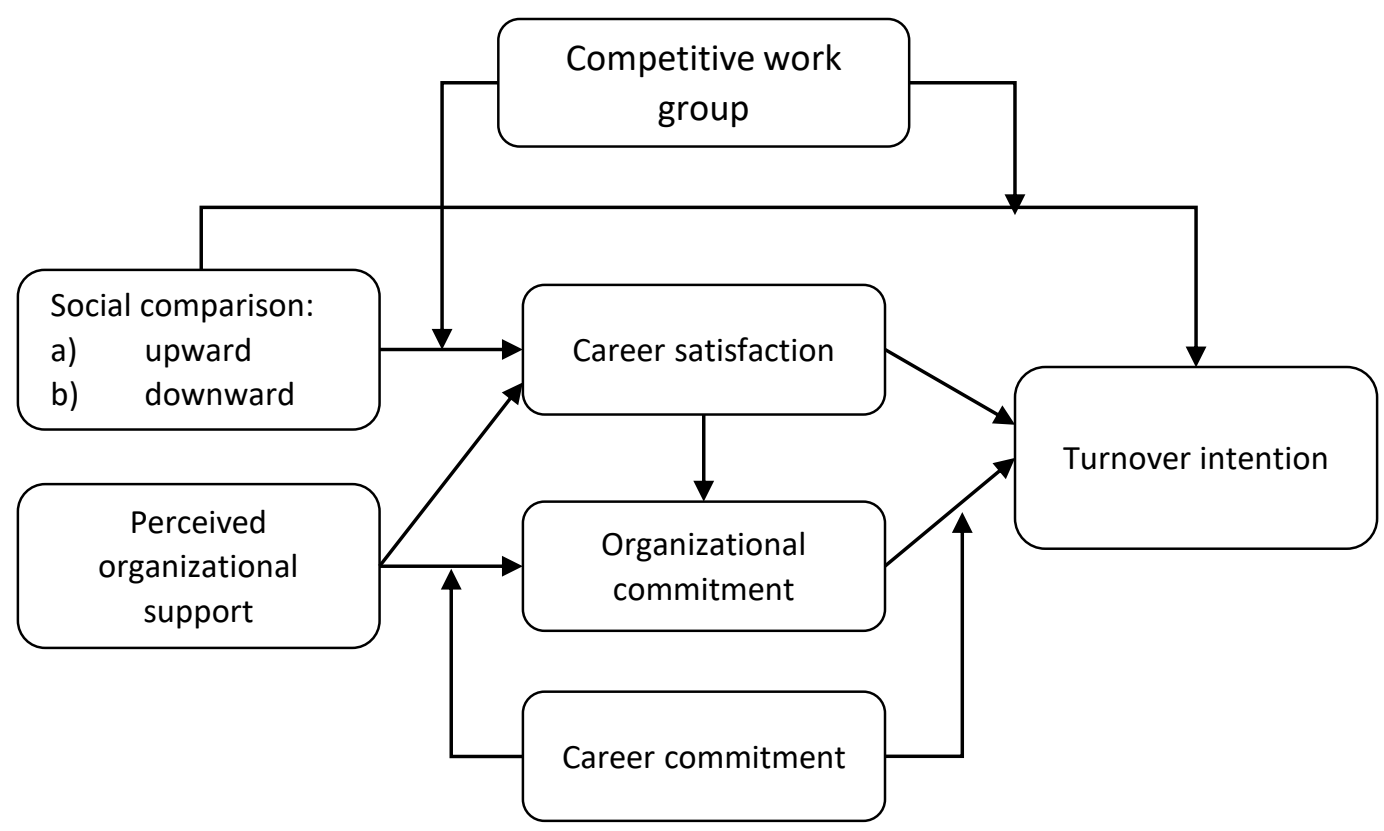

Figure 1. Conceptual model 
strong disagreement to the value of 5 to represent a strong agreement. The respondents in this research are full-time employees working for companies in Surabaya. From 440 questionnaires distributed, 302 questionnaires were submitted with a response rate of $68.6 \%$. Respondent details in this research are as follows: $69.2 \%$ male and $30.8 \%$ female, $75.2 \%$ married, $24.8 \%$ single, $20.5 \%$ are under 40 years old, and $79.5 \%$ are over 40 years old. From all the res ployee to compare himself with a more successful person. A downward comparison is the tendency of an employee to compare himself with more inferior people. The indicators used adopt the nine items of measurement from Eddleston (2009), consisting of four measurement items for the upward social comparison variable and five measurement items for the downward social comparison variable.

- Competitive work group. This is the level of competition among members of a work group. The indicators used adopt six measurement items by Eddleston (2009).

\section{RESULTS}

\subsection{Outer model evaluation}

\subsubsection{Convergent validity}

The first evaluation on the outer model is the convergent validity. Convergent validity is measured using the value of outer loadings. Based on the value of outer loadings for the Upward social comparison variable consisting of indic ators USC1, USC2, USC 3 , and USC4, then indicators USC2 and USC3 must be removed from the model because they do not meet the cutoff value of 0.5 . The competitive work group variable, consisting of the indicators CWG1, CWG2, CWG3, CWG4, CWG5, and CWG6, also needs to have some of its indicators removed, which are indicators CWG1, CWG3, and CWG4. For the perceived organizational support variable, the indicator POS5 must be removed from the model because it has a value under 0.5 , leaving indicators POS1, POS2, POS3, POS4, and POS6 in the model. Next, two indicators of turnover intention must be removed. They are indicators TI7 and TI9, leaving indicators TI1, TI2, TI3, TI4, TI5, TI6, TI8, and T10 in the model. There are three indicators of the career commitment variable that need to be removed from the model, which are indicators CC1, CC3, and CC4, leaving indicators $\mathrm{CC} 2, \mathrm{CC} 5, \mathrm{CC} 6$, and $\mathrm{CC} 7$ in the model. Lastly, the organizational commitment variable has one indicator that has to be removed, which is indicator OC1, leaving indicators $\mathrm{OC} 2, \mathrm{OC} 3, \mathrm{OC} 4$, OC5, and OC6 in the model. Variables of downward social comparison and career satisfaction do not have indicators in need of removal from the model because all indicators of both variables have met the cut-off value of 0.5 .

\subsubsection{Discriminant validity}

The second evaluation is the discriminant validity which is measured by comparing the squared value of AVE with the correlation value between latent variables where the squared value of AVE must be larger than each correlation value of latent variables. The table below shows that all variables have met the discriminant validity criteria.

\subsubsection{Internal consistency reliability}

The third evaluation is the internal consistency reliability evaluation, dedicated to test the reliability of measured variable. The evaluation is performed using a composite reliability score where the cutoff value is at 0.6. based on the value of composite reliability shown in Table 1, it can be seen that the USC variable does not meet the reliability requirement, while other variables have met the reliability cutoff value. Cooper and Schindler (2014) stated that validity test is the most important aspect in the evaluation of a measurement model compared to reliability tests. Therefore, if the reliability test is not fulfilled, as long as the validity test is fulfilled, the analysis may be continued.

\subsection{Inner model evaluation}

\subsubsection{Coefficients of determination $\left(R^{2}\right)$}

The coefficients of determination value of the variables of career satisfaction, organizational commitment, and turnover intention are 0.294, 0.547, and 0.600 , respectively.

Significance of path coefficients (hypothesis testing)

The result of path coefficients shows that hypotheses $1,3 b$, and 4 are accepted with $t$-statistics 
Table 1. Inner model evaluation

\begin{tabular}{|c|c|c|c|c|c|c|c|c|c|c|c|c|c|c|}
\hline & $\mathrm{CC}$ & CS & CWG & DSC & $\begin{array}{l}\text { DSC* } \\
\text { CWG } \\
\end{array}$ & $\begin{array}{l}\text { DSC* } \\
\text { CWG } \\
\end{array}$ & OC & $\begin{array}{l}\text { OC* } \\
\text { CC } \\
\end{array}$ & POS & $\begin{array}{l}\text { POS* } \\
\text { CC }\end{array}$ & TI & USC & $\begin{array}{l}\text { USC* } \\
\text { CWG } \\
\end{array}$ & $\begin{array}{l}\text { USC* } \\
\text { CWG } \\
\end{array}$ \\
\hline CC & $50 *$ & - & - & - & - & - & - & - & - & - & - & - & - & - \\
\hline $\mathrm{CS}$ & 307 & $837^{*}$ & - & - & - & - & - & - & - & - & - & - & - & - \\
\hline CWG & 054 & 0.221 & $0.737^{*}$ & - & - & - & - & - & - & - & - & 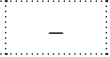 & - & - \\
\hline DSC & 196 & 0.256 & 296 & $0.786^{*}$ & - & - & - & - & - & - & - & $\ldots \ldots$ & - & - \\
\hline $\mathrm{DSC}^{*}$ & 345 & 0.402 & 0.315 & 0.236 & $0.542^{*}$ & - & - & - & - & - & - & - & - & - \\
\hline DSC*CWG & 0.365 & 0.374 & 0.317 & 0.231 & 0.970 & $0.540^{*}$ & - & - & - & - & - & I & - & - \\
\hline OC & 705 & 0.351 & 0.110 & -0.180 & 0.315 & 0.345 & $0.737^{*}$ & - & - & - & - & - & - & - \\
\hline $\mathrm{OC}^{*} \mathrm{CC}$ & -0.329 & -0.241 & -0.210 & -0.138 & -0.168 & -0.177 & -0.464 & $0.658^{*}$ & - & - & - & - & - & - \\
\hline POS & 0.621 & 0.192 & 0.131 & -0.039 & 0.308 & 0.328 & 0.570 & -0.298 & $0.727^{*}$ & - & - & - & - & - \\
\hline $\mathrm{POS}^{*} \mathrm{CC}$ & -0.319 & -0.158 & -0.126 & -0.061 & -0.168 & -0.172 & -0.332 & 0.751 & -0.441 & $0.600 *$ & - & - & - & - \\
\hline $\mathrm{TI}$ & -0.711 & -0.298 & -0.016 & 0.094 & -0.457 & -0.501 & -0.571 & 0.215 & -0.603 & 0.246 & $0.754^{*}$ & - & - & - \\
\hline USC & 0.513 & 0.134 & -0.162 & -0.406 & 0.187 & 0.216 & 0.448 & 0.019 & 0.335 & -0.032 & -0.447 & $0.759^{*}$ & - & - \\
\hline USC*CWG & -0.118 & -0.261 & -0.188 & 0.165 & -0.054 & -0.042 & -0.149 & 0.161 & -0.052 & 0.159 & -0.046 & -0.068 & $0.584^{*}$ & - \\
\hline USC*CWG & 0.181 & -0.049 & 0.085 & -0.047 & 0.292 & 0.302 & 0.167 & -0.101 & 0.191 & -0.042 & -0.260 & 0.047 & 0.352 & $0.569^{*}$ \\
\hline
\end{tabular}

Notes: $* \sqrt{A V E}$ value. $\mathrm{CC}=$ career commitment; $\mathrm{CS}=$ career satisfaction; $\mathrm{CWG}=$ competitive work group; DSC = downward social comparison; $\mathrm{OC}=$ organizational commitment; $\mathrm{POS}=$ perceived organizational Support; $\mathrm{TI}=$ turnover intention; USC = upward social comparison.

value of $\geq 1.64$, specifically $1.755,1.883$, and 1.797 , respectively. Whereas the original sample value of the three hypotheses are 0.191 for hypothesis 1 , 0.310 for hypothesis $3 b$, and 0.144 for hypothesis 4 . Hypothesis 2 has a $t$-statistics value of 0.404 and an original sample value of 0.047 . This shows that hypothesis 2 is not accepted. Similarly, hypothesis $3 a$ has a $t$-statistics value of 0.902 and an original sample value of 0.179 , which means that hypothesis $3 \mathrm{a}$ is also not accepted. Hypotheses 5, 6, 7a, and $7 b$ are collectively not accepted due to $t$-statistics values of $0.335,0.810,0.601$, and 0.226 , respectively. The original sample value for the three hypotheses are -0.031 for hypothesis $5,-0.104$ for hypothesis 6 , and -0.066 and -0.024 for hypotheses $7 a$ and $7 b$, respectively.

From the six moderated hypotheses in this research, three are accepted, which are hypotheses $10 a, 10 b$, and $11 b$. The t-statistics value of the three hypotheses are 1.701, 2.195, and 2.753, respectively. Whereas the original sample value for hypothesis $10 \mathrm{a}$ is -0.280 , for hypothesis $10 \mathrm{~b}$ is 0.260 , and for hypothesis $11 b$ is -0.265 . The three other moderated hypotheses, which are hypotheses 8,9 , and $11 a$, are not accepted. The statistics value of the three hypotheses are 0.345 , 0.306 , and 0.767 , respectively with original sam- ple values of -0.058 for hypothesis $8,-0.042$ for hypothesis 9 , and -0.084 for hypothesis $11 a$.

\section{DISCUSSIONS}

The result of the hypotheses testing shows that there are nine hypotheses which are not accepted. Hypothesis 2 shows that POS has a positive insigificant effect on career satisfaction. This may be caused by the characteristics of respondents with the majority aged over 40 years old and already married. Wong, Siu and Tsang (1999) stated that younger employees tend to be more career-oriented, whereas older employees will behave the other way around. For married employees, they tend to focus more on the balance between work and domestic life, therefore, not putting career as their main focus. Also, it can be said that the majority of respondents came from the Baby Boomers generation who are born between 1965 to 1980 (Yu \& Miller, 2004). The characteristics of this generation is how they tend to focus more on the balance between life and career, to work hard and to prefer a more stable job (Yu \& Miller, 2004).

Hypothesis 3a shows that upward social comparison has a positive insignificant influence towards 
career satisfaction. This may be caused by the fact that the majority of research respondents are aged over 40 years old. It was found in the research that younger employees tend to compare themselves with people who are better than them or they tend to have upward comparison. Conversely, employees aged over 40 years old tend to compare themselves with more inferior people. This is in correlation to the work comfort and loyalty of the employees, considering that respondents of this research are dominated by employees who have been working for more than four years in their current company. Eddleston (2009) stated that someone with the tendency to compare himself with more inferior people may have an increase of self-esteem, which will increase the satisfaction with his career and will tend to be more loyal to his company. So, an employee like this tends to not have any intention of leaving the organization. This also explains the results of hypotheses $7 a$ and $7 b$ where both upward and downward social comparisons do not have a significant effect on the employee's intention of leaving the company. This is also caused by the fact that the majority of the employees are aged over 40 years old and have been working for more than four years in their current company. Additionally, the fact that the employee status is dominated by those who are already married and of the male gender becomes the consideration on why employees would choose to stay in the organization, which is due to their responsibility as the head of the family. This can also be related to the insignificant effect of competitive work group towards the relation between upward social comparison and turnover intentions as stated in hypothesis 11a. It can be explained in more detail that the level of competition in a work group does not have any significance in the correlation because employees tend to choose to be loyal and to stay in their current company.

The fact that the majority of respondents are aged over 40 years old and have been working for more than four years can also be the reason why hypothesis 5 is not accepted. Igbaria and Greenhaus (1992) stated that older employees and those with longer work experience has a lower intention of leaving the organization. Also, Harold E. Burt in As'ad (2003, p. 35) stated that the older the employee is, the higher his tolerance towards dissatisfaction will be. So, even if the employee is dis- satisfied, this will not affect the employee to leave the organization. Similarly, this is related to hypothesis 6 that states that organizational commitment has an insignificant negative effect on turnover intention. As has been explained before that individuals over 40 years old tend to have a lower rate of turnover, so even if an employee does not have a strong commitment to current organization, it will not affect that employee to leave the organization. This goes in line with the research by Emiroglu et al. (2015) which also stated that individuals over 40 years old have a lower rate of turnover compared to individuals aged under 40 years old.

Hypotheses 8 and 9 test the effect of career commitment on the correlation between POS and organizational commitment and between organizational commitments. It was shown that career commitment does not have a moderating effect on those two correlations. This may be caused by the fact that the careers are not specific. Respondents in this research has positions which can be held by individuals of any background. Unlike careers such as doctors, lawyers, or policeman, the careers of the respondents are not careers that require any specific knowledge. So, they do not feel bound to their careers. Lin and Chen (2004) stated a similar result from the hypothesis that predicted a high career commitment would reinforce the correlation of POS with organizational commitment, and the result is also not accepted. Also, the hypothesis that predicts that low career commitment reinforces the correlation between organizational commitment and turnover intention is also not accepted. In that research, it was explained that career commitment to a non-specific career becomes a factor of the insignificant results found in the two hypotheses.

\section{FUTURE RESEARCH}

Future research should include the use of POS indicators that is more focused on career. Thus, exploration of the three types of commitment consisting of normative, affective, and continuance will develop better understanding of the effect of POS on each of the commitment types. Greater variability of the respondent's ages would increase sampling representation. 


\section{CONCLUSION}

In conclusion, support from organization regarding employee's career development could affect employee's commitment towards his organization. Beside support, employees who are satisfied with their career could improve their commitment toward organization. From individual perspective, employees who have a tendency to compare themselves to their inferiors would be more satisfied with career as their self-esteem improved. Moderating effects indicates that employee with upward comparison would be less satisfied with their career when they are working in a work group with high level of rivalry. Conversely, employees with a tendency towards downward comparison would be more satisfied with their career and decrease the intention to leave the organization.

\section{REFERENCES}

1. Abelson, M. A. (1987). Examination of avoidable and unavoidable turnover. Journal of Applied Psychology, 72, 332-386.

2. Aryee, S., \& Kevin Tan (1992). Antecedents and outcomes of career commitment. Journal of Vocational Behavior, 40, 288-305.

3. Aryee, S., Chay, Y. W., \& Chew, J. (1994). An investigation of the predictors and outcomes of career commitment in three career stages. Journal of Vocational Behavior, 44(1), 1-16.

4. As'ad, Moh (2003). Psikologi Industri. Yogyakarta: Galia Indonesia.

5. Barnett, B. R., \& Bradley, L. (2007). The impact of organizational support for career development on career satisfaction. Career Development International, 12(7), 617-636. https://doi. org/10.1108/13620430710834396

6. Blau, G. (1989). Testing generalizability of a career commitment measure and its impact on employee turnover. Journal of Vocational Behavior, 35(1), 88-103. https://doi. org/10.1016/0001-8791(89)90050-X

7. Blau, G. J. (1988). Management and prediction of career commitment. Journal of Occupational Psychology, $85,227-88$.

8. Buunk, A. P., \& Gibbons, F. X. (2007). Social Comparison: the End of a Theory and the Emergence of a Field. Organizational Behavior and Human Decision Processes, 102, 3-21.
9. Capelli, P. (2000). Managing without commitment. Organizational Dynamics, 28(4), 11-24. Retrieved from http://www. sciencedirect.com/science/article/ pii/S0090261600000085

10. Chang, E. (1999). Career commitment as a complex moderator of organizational commitment and turnover intention. Human Relations, 52(10), 1257-1278. Retrieved from http://journals.sagepub.com/doi/ abs/10.1177/001872679905201002

11. Eddleston, K. A. (2009). The effects of social comparison on managerial career satisfaction and turnover intentions. Career Development International, 14(1), 87-110. https://doi. org/10.1108/13620430910933592

12. Eisenberger, R., Huntington, R., Hutchison, S., \& Sowa, D. (1986). Perceived organizational support. Journal of Applied Psychology, 71, 500-507.

13. Emiroglu, B. D., Akova, Orhan., \& Tanriverdi, Haluk (2015). The relationship between turnover intention and demographic factors in hotel businesses: A study at five star hotels in Istanbul. Procedia - Social and Behavioral Sciences, 207, 385-397.

14. Erdogan, B., Kraimer, M. L., \& Liden, R. C. (2004). Work value congruence and intrinsic career success: the compensatory roles of leader-member exchange and perceived organizational support. Personnel Psychology, 57(2), 305-332. https://doi. org/10.1111/j.1744-6570.2004 tb02493.x

15. Gouldner, A. W. (1960). The norm of reciprocity: a preliminary statement. American Sociological Review, 25, 161-178.

16. Greenhaus, J. H., Parasuraman, S., \& Wormley, W. M. (1990). Effects of race on organizational experiences, job performance evaluations, and career outcomes. Academy of Management Journal, 33(1), 64-86.

17. Heslin, P. A. (2003). Self- and other-referent criteria of career success. Journal of Career Assessment, 11(3), 262-86.

18. Kim, Y. G., Kim, S., \& Yoo, J. L. (2012). Travel agency employees' career commitment and turnover intention during the recent global economic crisis. The Service Industries Journal, 32(8), 1247-1264.

19. Lee, C. H., \& Bruvold, N. T. (2003). Creating value for employees: investment in employee development. International Journal of Human Resource Management, 14(6), 981-1000.

20. Lin, C. P., \& Chen, M. F. (2004). Career commitment as a moderator of the relationships among procedural justice, perceived organizational support, organizational commitment, and turnover intentions. Asia Pacific Management Review, 9(3), 519-538.

21. Mobley, W. H. (1977). Intermediate linkages in the relationship between job satisfaction and employee 
turnover. Journal of Applied

Psychology, 62(2), 237-240.

22. Mowday, R. T., Steers, R. M., \& Porter, L. W. (1979). The measurement of organizational commitment. Journal of vocational behavior, 14(2), 224-247.

23. Ng, T. W., Eby, L. T., Sorensen, K. L., \& Feldman, D. C. (2005). Predictors of objective and subjective career success: A metaanalysis. Personnel psychology, 58(2), 367-408.

24. Portalhr. (2014). 78,3\% Karyawan Tidak Punya Jenjang Karir yang Jelas. Retrieved from http://www. portalhr.com/berita/783-karyawan-tidak-punya-jenjang-karir- yang-jelas/ (accessed on April 9, 2014).

25. Seibert, S. E., \& Kraimer, M. L. (2001). The five-factor model of personality and career success. Journal of Vocational Behavior, 58, 1-21.

26. Tansky, J. W., \& Cohen, D. J. (2001). The relationship between organizational support, employee development, and organizational commitment: An empirical study. Human Resource Development Quarterly, 12(3), 285-300.

27. Wang, L., Tao, H., Ellenbecker, C. H., \& Liu, X. (2012). Job satisfaction, occupational commitment and intent to stay among Chinese nurses: a crosssectional questionnaire survey. Journal of advanced nursing, 68(3), 539-549.

28. Wong, S., Siu, V., \& Tsang, N. (1999). The impact of demographic factors on Hong Kong hotel employees' choice of job-related motivators. International Journal of Contemporary Hospitality Management, 11(5), 230-242.

29. Yu, H. C., \& Miller, P. (2005). Leadership style: The X Generation and Baby Boomers compared in different cultural contexts. Leadership \& Organization Development Journal, 26(1), 35-50. 